\title{
5 \\ Languages of the Wik Native Title Claim Area
}

\author{
Peter Sutton
}

\section{Regional macro-groupings}

Most of the ethnological literature sources on the area between the Mission and Edward rivers that predate the 1970s couch their maps and group descriptions in terms of relationships between languages and land areas. ${ }^{1}$

Above that level, the classical social and cultural macro-groupings along the coast in the region between what are now Old Mapoon and Pormpuraaw were basically three (here dealt with from north to south). Macro-groupings 2 and 3 belong to the Native Title Claim Area, and macro-grouping 1 does not.

\section{Macro-grouping 1}

From Port Musgrave to Albatross Bay about a dozen or so clans owned among them three or four distinct but closely related languages. No cover term for them is available but their general cohesiveness is clear from the literature (Roth 1900; Crowley 1981 particularly). After colonisation, these groups settled at Mapoon (begun 1891) and dominated its early

1 See Maps 16-22 in Sutton (1978) and Maps 3.1-3.7 above. 
population. North of them and covering the whole tip of Cape York Peninsula the clans owned dialects of a single, but different, language that has been described by Crowley (1983) under the title of Uradhi.

\section{Macro-grouping 2}

From Albatross Bay to just south of Archer River, ${ }^{2}$ along a narrow coastal strip, are the estates of the Wik-Way people, whose clans own a set of closely related languages, which are clearly different from those to the south of them but middlingly related to those of the Mapoon area (see 1 above). These people formed the core of the Weipa Mission and part of the core of Aurukun Mission as they were established, respectively, in 1895 and 1904. On the eastern or inland side of the Wik-Way estates, on the upper Watson River, Kokialah Creek, and north to the middle Embley and Myall Creek areas, are the estates of clans whose members are not identified as Wik-Way in the modern sense, but whose languages are most closely related to those of the Wik-Way grouping.

In earlier times it seems clear, from Ken Hale's and Norman Tindale's work in the 1960s for example, that 'Wik-Way' was a term applied, from a south-of-Archer (Wik Subgroup) perspective, to any language to the north, including the inland ones such as Mbiywom and Ngkoth of the upper Watson and Hey rivers respectively.

The current senses of this term are narrower. One, for example, has the Wik-Way area running from the Aurukun Airstrip (north side) via Ikeleth and the Ward River, north to Embley River, excluding the Watson River system and Oyenten. This is the predominant sense of the term among those to whom it applies at Aurukun.

\section{Macro-grouping 3}

From about Love River south to Moonkan Creek and inland to about Rokeby, Meripah, and the upper Holroyd, and from there in a narrow band east to Princess Charlotte Bay, are the estates of the clans owning languages that are members of what is called here the 'Wik Subgroup' of languages. These five distinct languages and their many named dialects form a distinct genetic subgroup within the Cape York Peninsula (Paman) language family.

2 See Wik-Paach estates 43 and 44, Map A2.3 this volume. 
Philip Hamilton has established that Pakanh and Ayapathu, languages associated with the uplands and Great Dividing Range between the upper Holroyd River system and the coast at Princess Charlotte Bay, are genetically part of the Wik Subgroup and are close dialects of a single language. ${ }^{3}$ It appears, however, that only those affiliates of Pakanh and Ayapathu with estates close to the Wik heartland are socially and culturally integrated with the Wik peoples. This is why the country of such people was included in the Wik native title application. ${ }^{4}$

A number of the relevant historical and anthropological records identify people of this south-eastern interior area, the upper Kendall and Holroyd River systems, not by estate totemic centres or by language but by a geographically broad environmental typifier, Pechem (Wik-Mungkan), Pachem (Wik-Ngathan), meaning 'those from open country' (cf. 'Wik Patjam' in Thomson 1972:vi). Pech (Mn) and pachel (Nn) are adjectives meaning 'clear, open, white'. They are used to denote savannah landscapes.

It is typical of Aboriginal Australia that the Wik bloc should be relatively clearly defined at the coast, but is less rigidly defined in the less resourcerich inland: the greater the scarcity, the more mobile the original population would have been and the more outward-looking their approach to inter-group relations (Sutton and Rigsby 1982). It is also typical that people whose countries lie along the upper watersheds should have affiliations and associations with those downstream from them on more than one side of their uplands. Thus, while a number of Ayapathu people, for example, have links to mainstream Wik people and indeed have a Wik-Subgroup-type language, in the past some of them had estates at Princess Charlotte Bay in the area of Running Creek. Succession to these estates has been by the Port Stewart Lamalama (Rigsby and Hafner 1994). From a west coast perspective, however, the Wik cultural bloc may be seen quite properly to fade out on the upper Holroyd system in the south-east, and not to extend right to the east coast.

3 Philip Hamilton, pers. comm., 29 March 1997.

4 For details of Ayapathu people with countries close to or part of the Wik Region see Chase et al. (1998:79-95). 


\section{Land/language affiliations between the Archer and Mission rivers: Wik-Way-type languages}

Here I discuss the area covered by Macro-grouping 2 above, proceeding to survey the literature on each language running approximately from north to south. Before doing so, I discuss in more detail the content of the broad geopolitical categories 'Wik-Way' and 'Winda-Winda'.

\section{Languages covered by the term Wik-Way}

As is often the case in Aboriginal Australia, where regional macro-group terminology is concerned, and as noted above, the term Wik-Way was originally an outsider's term. It means 'Language-Bad/Difficult' in several of the languages of the Wik Subgroup, e.g. in Wik-Mungkan, WikNgathan, and others. It has now become a self-designation at least among those Wik-Way who live in the Aurukun Shire and many who live at Napranum.

It is a term with more than one legitimate meaning. It seems to have long had at least two ranges of reference, a narrow sense and an extended sense, although the narrow sense may now be dominant (the 'modern sense', see Chapter 3: The Wik-Way). I now examine all available lists of languages coming under these ranges of reference. Note that here I transliterate the ethnographers' spellings into a 'Standard' spelling that is not only for the most part linguistically more accurate but also provides language names in the form used within the relevant language. This accounts for some systematic differences between the two (e.g. the self-named Ndrwa'ngathi is called Ndrwa'ngith in some other languages whose comitative suffix is different, and for the same reason Arrithinngithigh appears to have been called Arrithingwom in Mbiywom).

\section{Thomson}

In 1933 Donald Thomson (1933:File no. 276, undated), presumably at Aurukun, recorded two lists of languages known collectively as 'WikWay' by people speaking Wik-Mungkan, and in each case the lists were subdivided into a primary list and a secondary list. The latter was introduced in his notes by the word 'Also...' in one case, and bracketed below the main list in the second. The added languages may represent afterthoughts 
by his informants. With two exceptions (Thomson's 'N'got'tungit', which is Ngkoth as pronounced in another language probably as Ngkothngith; and 'Tan'ngat', which is Thanikwithi as pronounced in another language, probably as Thyanngayth), the primary list in each case refers to languages from between the Archer and Watson rivers in the south and the Mission and Wenlock rivers in the north. The secondary or additional languages specified belong to the next macro-grouping north of there between Albatross Bay and Port Musgrave.

Table 5.1: Thomson's lists of Wik-Way language varieties

\begin{tabular}{|l|l|l|}
\hline THOMSON LIST 1 & THOMSON LIST 2 & STANDARD \\
\hline Additin'ngitti & Adedingit & Aditinngithigh \\
\hline Lin'ngitti & Lin'ngitti & Linngithigh \\
\hline $\begin{array}{l}\text { N'dwangit (gerri'gerri) } \\
\text { [listed under Lin'ngitti \& } \\
\text { bracketed as 'Same'] }\end{array}$ & N'drangit & Ndrwa'ngathi \\
\hline Latum'ngit & Latum'ngit & Latumngith \\
\hline Andjingitti & Andjingit & Andjingith \\
\hline Alingit & Alingit & Alngith \\
\hline Aredin'ngit & Aredinngit & Arrithinngithigh \\
\hline Mberwum & M'berwun & Mbiywom \\
\hline N'dra'ngit & N'drangit & Ndra'ngith \\
\hline- & Lin'ngit & $\begin{array}{l}\text { ?Laynngith } \\
\text { [= Alngith] }\end{array}$ \\
\hline- & Ngernbudi & - \\
\hline [On edge of page:] & [Bracketed:] & Tjungundji \\
\hline
\end{tabular}

Table 5.2: Thomson's 'also' list of Wik-Way language varieties

\begin{tabular}{|l|l|}
\hline THOMSON'S 'ALSO' LIST & STANDARD \\
\hline Yangit [Yangith?] & Yangathimri ${ }^{5}$ \\
\hline Yin'wum & Yinwum \\
\hline Tiep'the [Tyaepthi?] & Taepadhighi \\
\hline M'bawsan & Mbaatjan \\
\hline O'ngit & [cf. Alngith] \\
\hline
\end{tabular}

5 Cf. AnguThimri (Crowley 1981). 


\begin{tabular}{|l|l|}
\hline THOMSON'S 'ALSO' LIST & STANDARD \\
\hline Watjanwum & $-{ }^{6}$ \\
\hline Tan'ngat [Thyanngayth] & Thanikwithi \\
\hline O'natangit [Anathangith] & Anathangayth \\
\hline N'got'tungit [Ngkothngith] & Ngkoth \\
\hline Otak & - \\
\hline
\end{tabular}

\section{McConnel}

Ursula McConnel expanded her knowledge of groups north of the Archer River during her 1934 field work at Aurukun, Weipa and Mapoon (1936:69; 1939-40:59).

In her writings she does not mention the term Wik-Way, but her discussions of language-related groups and their land associations (especially 1939-40:57-64) suggest some subgroupings that are relevant here. For example, she devotes a single paragraph to a discussion of nine languages (listed below, see discussion of Winda-Winda) whose owners had land between the Embley River and Wallaby Island in the mouth of the Archer. It is of interest that she does not include Mbiywom in this list, but discusses it in the context of inland groups having the languages Yinwum, Trotj, and (inland) Kaantju. Trotj, however-which was very close linguistically to Ngkoth (Hale 1966:165) —is also discussed (along with Ngkoth) as part of her list of nine languages between the Embley and Archer rivers. She placed Mbiywom in a 'northern group' in terms of social organisation, a group described as those from 'north of the Watson River' (1939-40:64).

McConnel (1939-40:60) referred to at least a number of these languages as those that had names suffixed with '-Niti' or '-Nati' - that is, names of their languages tended to end in the comitative suffix -ngithi, -ngithigh, or -ngathi. Note that these would be appropriate suffixes in which to name the languages from within only a few of them, such as Linngithigh in the case of -thigh, or -ngathi in the case of Mamangathi. In other languages the same languages may be named using distinct but mostly related and semantically equivalent suffixes, e.g. -ngith, -ngayth, -wom.

6 On -wum, cf. Mbiywom, Yinwum, Arrithingwom, see this chapter, Code L12. 


\section{Gajdusek}

In 1956, Daniel Carleton Gajdusek, a genetics researcher, visited Weipa and recorded a list of 'small tribes which the Wik-Mungken [sic] refer to as the Wik-Waiya (meaning "speech bad"), clustered about Albatross Bay at the mouths of the Mission, Hey, and Embley Rivers' who had been centralised at Weipa (Simmons et al. 1958:64-5):

Table 5.3: Gajdusek's list of Wik-Way language varieties

\begin{tabular}{|l|l|}
\hline GAJDUSEK & STANDARD \\
\hline Wimmarango & Wimaranga \\
\hline Tanikutti & Thanikwithi \\
\hline Lainingitti [Laynngithi] & Alngith \\
\hline M-Berwum (Bywoom) & Mbiywom \\
\hline N-Dwangit (Dragnite) [Ndrwa'ngayth] & Ndrwa'angathi \\
\hline Linngitti & Linngithigh \\
\hline Aredinngit [Aritinngith], (Aritchenite [Aritinngayth]) & Arrithinngithigh \\
\hline Latumngit & Latumngith \\
\hline
\end{tabular}

(Apart from Wimaranga, which is from the coast just north of Albatross Bay [Capell 1963: Y-25], and a language of macro-grouping 1 described above, the others are all of macro-grouping 2.)

Gajdusek then listed 'other tribal names of the region' as:

Table 5.4: Gajdusek's 'other' list of Wik-Way language varieties

\begin{tabular}{|l|l|}
\hline GAJDUSEK & STANDARD \\
\hline Yeemwoom & Yinwum \\
\hline Teepani & [?Taepadhighi] \\
\hline Gott & Ngkoth \\
\hline
\end{tabular}

He located two further languages (usually included in Wik-Way) north of the Archer on the coast:

Table 5.5: Gajdusek's north of Archer River Wik-Way language varieties

\begin{tabular}{|l|l|}
\hline GAJDUSEK & STANDARD \\
\hline Andjingit & Andjingith \\
\hline N'drangit & Ndra'ngith \\
\hline
\end{tabular}




\section{Hale}

In 1960 Ken Hale recorded the term Wik-Way as referring to all the languages north of the Watson River, a north-side tributary of the Archer River, as far as the tip of Cape York, all of which share aberrant sound systems and whose vocabularies are very different from those south of the Archer and Watson rivers (and indeed they vary a great deal among themselves) (Hale 1964:248). Thus in Hale's terms (1966:162), Wik-Way is equivalent to his Northern Paman linguistic subgroup of the Paman family. He sampled 13 Northern Paman languages and published a technical comparison of them along with a sketch grammar of one, Linngithigh (1966).

Hale listed those of which he had knowledge from north to south as follows (spellings here have been transliterated from phonemic symbols to keyboard characters, and only a few need to be standardised; standard forms are only supplied here where they differ, as self-designations, from the other-dialectal form recorded by Hale, or where Hale uses $/ \mathrm{Nt}-/$ and I use $/ \mathrm{Nd}-/)$ :

Table 5.6: Hale's list of Wik-Way language varieties

\begin{tabular}{|l|l|}
\hline HALE & STANDARD \\
\hline Uradhi & \\
\hline Mpalitjanh & \\
\hline Luthigh & \\
\hline Yinwum & \\
\hline Linngithigh & \\
\hline Alngith & Thanikwithi \\
\hline Thyanngayth & Mamangathi \\
\hline Mamngayth & Ndrwa'angathi \\
\hline Ntrwa'ngayth & Ndra'ngith \\
\hline The three above are collectively known as: Awngthim \\
\hline Ntra'ngith & \\
\hline Ngkoth & Arrithinngithigh \\
\hline Aritinngithigh & \\
\hline Mbiywom & \\
\hline
\end{tabular}

Apart from the first four, Hale located these languages between Albatross Bay and the Ward and Watson rivers and they are within macrogrouping 2, as described above. 


\section{Languages covered by the term Winda-Winda}

\section{Roth}

W.E. Roth (1910:96 and Plate XXXI) ${ }^{7}$ listed groups from the area between Port Musgrave and Pera Head and indicated their homelands on a map. South of the Embley these included the Gautundi (lower Hey R., coastal, standard spelling uncertain, possibly Ngkoth) and Winda-Winda 'who speak Marma-ngati' (i.e. Mamangathi) but who were identified rather expansively as 'around coast from Pera Head to the Mission River'. It is clear from later work that Mamangathi is indeed the language of the southern side of the mouth of the Embley but also that Winda-Winda is a broad cover term that includes Mamangathi but also many other linguistic varieties. Roth did not record the term Wik-Way, but he did his work at Mapoon and Weipa (at its old site on the middle Embley) before the establishment of Aurukun, so there is no reason why he should have come across the term 'Wik-Way'.

\section{McConnel}

McConnel (1939-40:62) said Roth's 'Windawinda' (sic), which she claimed meant 'windward', ${ }^{8}$ was a local name for 'some of the tribes recorded here', and in the same paragraph discussed the following languages associated respectively with these areas: between the Embley and Hey Inlet, up-river on Myall and Cox Creeks (Mission R.), False Pera Head, Hey Inlet, the lower Embley across to the then new location of Weipa Mission, Pera Head, south to the Archer River, both sides of the Ward River, and Wallaby Island in the Archer River mouth:

Table 5.7: McConnel's list of Wik-Way language varieties

\begin{tabular}{|l|l|}
\hline MCCONNEL & STANDARD \\
\hline Nggot & Ngkoth \\
\hline To.tj & Trotj \\
\hline Ndra'angit & Ndra'ngith \\
\hline Aritingiti & Arrithinngithigh \\
\hline Latamngit & Latumngith \\
\hline Alingit & Alngith \\
\hline Adetingiti & Aditinngithigh \\
\hline Leini-ngiti & Linngithigh \\
\hline Andyingit & Andjingith \\
\hline
\end{tabular}

7 There is more detail in the manuscript version Roth (1900:2-4).

8 I suspect this is a false etymology. For most of the year the area concerned is on the leeward side not the windward side. In any case, the word 'windward' in Cape York Creole is [windəd] not [windəwində]. 
In an earlier publication McConnel (1936:Part I:464) had recounted a myth from the 'Windawinda Creek' area and current official maps still have a 'Winda Winda Creek' between the Hey River and the coast. Hale (1966:176) referred to 'the Winduwinda area'. It seems likely that the origin of the term Winda-Winda is essentially geographical, centred on the Winda Winda Creek area, but loosely covering the groups with lands between the Archer and Mission rivers.

In that sense, as Tindale suggested (1974:190 and see below), we may take Winda-Winda to refer essentially to the same groups as the term Wik-Way in its narrower (and now more customary) sense.

\section{Tindale}

Norman Tindale (1963; 1974:189-90 and map) interviewed a man from the upper Hey River at Mornington Island in 1963. The informant's own language he recorded as A'retinget, but Tindale added in parentheses language variety names in more than one variety and from various literature sources. Tindale listed 12 'hordes or incipient small tribes' (1974:189 and map; Map 3.5 in this volume) under the broad designation Winduwinda (cf. Winda-Winda), providing locations for each (locations and associated people are listed later in this chapter in the summary of sources):

\section{Table 5.8: Tindale's list of 'Winduwinda' (Wik-Way) language varieties}

\begin{tabular}{|l|l|}
\hline TINDALE & STANDARD \\
\hline I Tanikuit [Thanikwith], (Tannikutti, Dainiguid, Tannagootee) & Thanikwithi \\
\hline II Ndruangit [Ndrwa'ngith] & Ndrwa'angathi \\
\hline III Ndwangit [Ndwa'ngith], (Ndwongit) & ?Ndwa'angathi \\
\hline IV Ngawangati (Ngawateingeti, Ungauwangati) & ?Ngawangathi \\
\hline V Alingit (Lengiti, Lenngiti, Alngid, Limretti [?typographical error] $]^{9}$ & Alngith \\
\hline VI Mamangit [Mamangith], (Mamangiti, Mamngaid) & Mamangathi \\
\hline VII Latamngit (Lätamngit) & Latumngith \\
\hline VIII Nggot (Gott) & Ngkoth \\
\hline IX Aretinget [Arrithinngith] & Arrithinngithigh \\
\hline X Ndraangit & Ndra'ngith \\
\hline XI Leningiti & Linngithigh \\
\hline XII Andjingit & Andjingith \\
\hline
\end{tabular}

9 Tindale's suggestion. 
This is fairly precisely a listing of languages that belong to the same subgroup and are distinct at the subgroup level from both their northern neighbours (Anguthimri and related languages) and their southern neighbours of the Wik Subgroup.

They are all shown on Tindale's map as belonging to specific parts of the area between the Archer River and the north side of the Mission River. Tindale provides as an alternate name for this grouping 'Wikwija (sic; 'bad speech-name given by Wik-munkan)' (Tindale 1974:190)—i.e. WikWay (Tindale uses $/ \mathrm{j} /$ for $/ \mathrm{y} /$ ). A comparison shows that the list is very close to Thomson's core list of Wik-Way languages. Note, however, that Tindale's informant did not include Mbiywom (Tindale's Mbewum) in WindaWinda. The status of Mbiywom in relation to the Wik-Way category is still somewhat unclear, as befits its intermediate location on the margins of both coastal and hinterland Aboriginal systems. The status of Wik-Ompom is perhaps unclear (see Code: L19 below). Wik-Ompom and Mbiywom are as far as I know just different names for the same dialect.

Tindale's reluctance to call these entities 'tribes' is revealing. Their crime, as it were, was that they were so small as to look like stark contradictions of Tindale's (and Birdsell's) dialectal tribe model in which language groups usually had a few hundred people. On his 1974 map, Tindale noted the coastal Wik Subgroup language names under the heading 'Small Tribes', as if they just squeaked in as tribes. Inconsistently, he showed equally small language countries south-west of Darwin (Daly River to Port Keats) and at the mouth of the Murray River simply as 'tribes'. 


\section{Summary of sources on land/language affiliations between the Mission and Archer rivers}

The literature sources given below are much abbreviated, usually shown here only by a surname. Unless dates are specified, these citations refer as follows:

- $A a k=$ Sutton et al. (1990)

- Bos = Bos (1973-74)

- Capell = Capell (1963) unless specified otherwise

- Crowley = Crowley (1981)

- Gajdusek = Simmons et al. (1958)

- Hale = Hale (1966)

- Hinton: Hinton (1963)

- Martin = Martin (n.d.)

- Mathews = Mathews (1900)

- McConnel '28 = McConnel (1928)

- McConnel = McConnel (1939-40)

- Roth = Roth $(1900 ; 1910)$

- Sharp = Sharp (1939)

- Sommer = Co-ordata Research (1994)

- Sutton = Sutton (1976-93, field book 136)

- Thomson = Thomson $(1933 ;(\operatorname{map})=1972)$

- Tindale $=$ Tindale $(1974)$

Note that the tilde $(-)$ means 'alternating with'.

Languages are listed here approximately from north to south, from Mission River to Archer River. In two cases the survey extends south to the Love and Kirke rivers, where it can be shown that Wik-Way-type languages were the primary languages of affiliation at a remote time, having been gradually superseded by a Wik-type language in perhaps the late nineteenth century in one case, and the early twentieth in another. 


\section{Code: L1}

\section{Standard name: Thanikwithi}

Source spellings: Mathews (from Hey): Tannagootee; Roth: tai-ni kudi, te-ana-ngada; possibly also den-ya kudi; Thomson: Tan'ngat (1933), Tanikutti (map); McConnel: Tainikuit; Gajdusek: Tanikutti; Capell: Tainukwiti (1955) Dainiguid (1963); Hale: Thyanngayth; Tindale: Tanikuit; Bos: Taieningit, Thainikwit, Tainikwite, T(h)ainikwit(h); Crowley: Thanikwithi; Sommer: Thainikuith.

Source locations: Mathews: [on CYP, no detail]. Roth: 'Stretching between the Pennefather and Pine Rivers' (tai-ni kudi); 'living low down on the south side of the Batavia River' (de-nya kudi); Thomson: (map) On the coast between the Pine and Mission rivers; McConnel: (1939-40: map) Andoom area, coast at Andoomajettie Point; Capell: 'North coast of Albatross Bay, near Weipa'; Hale: 'lower Mission River'. Crowley: 'the mangrove area north of the Mission River' (+ map); Bos: $\mathrm{N}$ of Mission River, including Ndheerang (swamp), Mbootjeth [cf. map Bochet Creek], Ndhun-ndhuning-dja - Ndhunndhuningdhya; Andoom, Ndherrang (swamp); Lwreeng, Luuth, Tji(ng)-tji(ng), Paingga, Treeng, ?Thumubwon; Sommer: Luenh, Mbuining, Ndhumdjith, Prunang, Ughindhing, Wanggath.

People: Bos: Cyril Hall, Kitty Dick, Eva York, Eric Paul, Joyce Hall, Mildred Barkley, Hilda Jingle, Gloria Fletcher; Sommer: Halls.

Comments: Roth: tai-ni kudi = 'mangrove'; They speak ang-a dimi (the 1st pers. pronoun) [i.e. Awngthim as said in Anguthimri?]; den-ya kudi = 'bush'. Roth also gives te-ana-ngada (te-ana = '1st. pers. pronoun') as the language of the $\mathrm{O}$-amro=koro ('around the lower reaches of the Mission River'), a term not so far identified. Hale: from thyanh 'spearthrower', hence possibly Thyanhngayth. Crowley: Called Thyanngayth by the Linngithigh, language is Awngthim.

\section{Code: L2}

\section{Standard name: Ndrwa'angathi}

Source spellings: McConnel: Ndru'angit; Tindale: Ndruangit; Hale: Ntrwa'ngayth; Crowley: Drwa'angathi [Crowley's $/ \mathrm{Dr} /$ = my /Ndr/]; Bos: NdRwanget; Sommer's Ndrrua'ngaith - Nrrua'ngaith - Ndrua'ngaith anomalously relates to sites which fall within the area of L3 below. 
Source locations: McConnel: (map) Andoom area between Pine and Mission rivers; Hale: 'lower Mission River'. Tindale: 'North side of Mission River' + map (map has it between Pine and Mission rivers). Crowley: 'in the Mission River area' map: north side of lower Mission River.

People: [information not available]

Comments: Hale: they speak Awngthim; Crowley: called Draw'ngayth [i.e. Ndraw'ngayth in our orthography] by the Linngithigh.

\section{Code: L3}

\section{Standard name: Ndrrangith}

Source spellings: Sutton (Book 83:133): Ndrrangith; Possibly Hinton: Ndrangit; Sommer: Ndrrua'ngaith - Nrrua'ngaith - Ndrua'ngaith (anomalous).

Source locations: Sutton: north side of lower Embley River at Wathayn. Sommer: Brumby Hole, Kuamther, Mandjunggar, Waram Thain.

People: Sutton: language of Clan 83 (Coconut); cf. Hinton: Norman Paul, Samualas.

\section{Code: L4}

\section{Standard name: Ndwa'ngith}

Source spellings: Thomson: N'dwangit (gerri-gerri); McConnel: Ndwangit; Gajdusek: N-Dwangit (Dragnite); Tindale: Ndwangit (Ndwongit).

Source locations: Thomson: (map) Urquhart Point area; McConnel: 'middle Mission River, north \& south sides' + map (map has it north side at least); Tindale: 'North side of Mission River' + map (map has it straddling lower Mission River).

People: Thomson: [connection with Linngithigh unclear:] Billy Blowhard, Blink Jack, Tankappi, Anang'gan.

Comments: Thomson's location is odd; the balance of sources suggests Mission River. 


\section{Code: L5}

\section{Standard name: Ngwathangathi}

Source spellings: Sharp: Ngwatangeti; McConnel: Ungauwangati; Capell (1963) mentions Ngwataingeti 'used by D. Moore as an alternative [to 'Windawinda'], but on unstated authority'; Tindale: Ngawangati.

Source locations: Sharp: (map) lower Mission River; McConnel: 'on the south side of the Mission River' + map; Tindale: 'lower Mission River' (+ map, which has them on south side of mouth of Mission River).

People: [information not available]

Comments: Compare the basis of the name of Ngkoth (from ngko 'this') - Ngkoth-ngith, and Capell's recording of Ngkoth as Nggwat.

\section{Code: L6}

\section{Standard name: Anathangayth}

Source spellings: Thomson: O'natangit; Hinton (1964 map): Onnatangnit Sutton: Anathangayth; Sommer: Anhathangaith.

Source locations: Hinton (1964 map): upper Hey River; Sutton: 20-mile (old Weipa Mission) and upstream along Myall Creek etc. (Estate 68); Sommer: Billy Lagoon, Kurrico Creek, Myall Creek (place mayal [site name]) Cox Creek and so on, Waipa (old mission site), Bingay, Jabiru Scrub, Nonda Spring, Yipatjiku [Kaantju name].

People: Sutton: Alice Mark and siblings, her father and siblings, her FF Okolkon.

\section{Code: L7}

\section{Standard name: Alngith}

Source spellings: Roth: Laini-ngadi (see Hale below); Thomson: map: Lainingitti (see Hale below), MS: Alingith (and cf. MS: O'ngit); McConnel: Alingit; Sharp: Lenngeti; Gajdusek: Lainingitti; Hinton: Arangit (1963), Alang yit (1964); Tindale: Alingit; Capell: Alngid; Hale: Alngith (= Laynngith); Bos: Lainingit, Lainngit, Laininget, Lainingt, 
Liiningeth, Alnget, Alngeth, Alngaite; Martin: Alangithiy [Wik-Mungkan version]; Sommer; Alngith; Sutton: Alngith (Jean George, Chevathuns et al.), Laynngith (Johns, Maduas et al.).

Source locations: Roth: 'between the Pine and Mission Rivers (coastal blacks)' (map is the same); Thomson: (map) Weipa and east, between Mission and Embley rivers; McConnel: 'from the south side across the Embley River to where Weipa Mission is now situated' + map; Sharp: (map) Weipa area; Tindale: 'Weipa and east' + map; Hinton (1964 map): Weipa Peninsula; Bos: Uunanganam Unanganam Ck, Beening Ck, Gonbung - Gonbang, Trunding - TRandhing, Lorim [Point], KamRindje [Kumrunja Beach] Rocky [Point], Awonga ( - Oogwang), Bridge, Tchwembit, 'all [Weipa] town', Napranum, shell hill, Baang Point, Wallaby Island, across to Hey Point, Ndhrrilkiatj - Ndhrilkiiatj Ck, Trailak - Thrailak (swamp) [see map: Triluck Creek + marine swamp near mouth], as far as Coxy Point, Liithing - Liidhing [see map: Leithen Creek, Leithen Point], Anyiiyam Anyiam Ck, Nggorainam. Martin: (map) about Weipa airstrip, Jessica Point, south to about Cyclone Island; Sommer; Mbining, Mbuin Wuth (Cool Pool).

People: Thomson (Alingit): Old Dick, adding: 'all at Weipa'. Hinton: Eddie John. Bos: Liiningeth: Albert Chevathun, Andrew Chevathun, Jean George, Richard Kelinda, Betty Bowenda, Gideon Chevathun, Norma Chevathun, Christina Chevathun, Julie Chevathun, Joseph Chevathun, Trevor Chevathun, Roy Chevathun, descendants of Matthew Fruit; Alngeth: Eddie John, Ronnie John, Matilda John, Colleen John, Ron Nicholas, Aileen Heinemann, Susie Madua; 'Note: Liininget[h] may also claim country [of Alngeth].' Elsewhere: 'Richard [Kelinda] can claim here too. If Eddie [John] goes $>$ [then] Ronnie \& Richard to back up'. [recorded at Napranum]. Martin: Kelindas, Chevathuns (Gideon, Norma et al.), Jean George; this branch of Chevathuns is in fact Kelindas; Sommer: Johns.

Comments: Alngith and Laynngith are alternative names for one language (Hale). Old sources indicate Laynngith was also called Layningathi and Layningithi, presumably in different dialects. In Alice Mark's language (Anathangayth) the Johns' language is called Alangayth (PS Book 83:112). This is not inconsistent with Bos's phrase 'lainingt or alngaite' [sic] and the heading 'Alnget/Lininget' followed by 'Same people'. Kitty Dick told Bos that Jean George's language and the John family's language was, in ideal practice, the same. Bos also notes, however, that 'liningati-diff > 
[from] alnget' and 'alnget lininget different'. These references are probably to Linngithigh not Laynngith, especially since 'Fred' (Kerindun, see L15), whose language was Linngithigh, is here associated in Bos's notes with 'liningati' and 'Jean' (George) with 'alnget'. Alngith and Linngithigh are distinct but close dialects of a single language with no more than half a dozen good speakers remaining at Aurukun and Weipa in the 1960s (Hale).

\section{Code: L8}

\section{Standard name: Mamangathi}

Source spellings: Roth: marma-ngati; Sharp: Mamangeti; McConnel: Mamangiti, Ma.mangiti; Capell: Mamangidigh, Mamngaid; Hinton (1963): Mamangnit, Hinton (1964): Mamangit; Hale: Mamngayth; Tindale: Mamangit; Crowley: Mamangathi (called Mamngayth by the Linngithigh); Bos: Mamngaith, Mamngaitj, Mamnget; Sommer: Mamangaith.

Source locations: Roth: [referring to Winda-Winda, see Comments below] 'around coast from Pera Head to the Mission River' but map shows them only from Pera Head to the east side of the lower Hey; Sharp: (map) coast south of Albatross Bay; McConnel: (map) coast south of Albatross Bay; Hale: 'on Urquhart Point'; Tindale: 'South side of Albatross Bay' + map; Hinton (1964 map): Urquhart Point; Crowley: (map) Urquhart Point and south along coast; Bos: S of Embley, Baang $\rightarrow$ Thiitj lagoon + timber country, ?Lwemdjin lagoon, Urquhart Point; Sommer: Mangrove Creek, Aniyam, Mbang (Urquhart Point), Ndhandjiprin, Ndrrilkiyatj, Nggoray(thim), Prendjim, Trailak, Wul Ndrran.

People: Hinton: Arthur Dick, Stanley Coconut Snr.; Bos: Yorks, Georgy, Bobby, Dick, Esther, Henry; Sommer: Dicks.

Comments: Roth: marma-ngati $=$ first person pronoun, language of 'Winda Winda' people (see elsewhere); Hale: Mamngayth speak Awngthim. Clearly Mamangathi, Mamngayth, Mamangithigh are names for the same language, but as pronounced in different languages. The fact that the informants of various scholars had different language affiliations probably determines most of this variation in the record. One informant (Jean George) told PS that the Dicks' language was Nda'ngith, and that most others called it Ndrra'ngith (but it was the same language). This view is unusual. 


\section{Code: L9}

\section{Standard name: Latumngith}

Source spellings: Thomson: Latum'ngit; Sharp: Latangeti; McConnel: Latamngit; Gajdusek: Latumngit; Capell: Ladamngid; Tindale: Latamngit; Sommer: Lathumngith - Latumngith Latamngith; Sutton: Two main pronunciations, probably in different languages, have been recorded: Latumngith and Latamngith.

Source locations: Thomson: (map) between the middle Embley and the Hey; Sharp (map): about Hey River; McConnel: 'on Hey Inlet', (map) west side of Hey River; Tindale: 'West bank of Hay (sic) River' + map (map has it straddling the middle Hey River inlet); Sommer: Idholdja, Kokanin, Maingum (contested), Meunyam, Poghadhim, Thitj, possibly Pimpim; Sutton: Estate 53, west side of the middle Hey River.

People: Thomson: Doughboy, Saul; Sutton: Clan 52 (Blowhards, Ida Paul [mother of Joyce Hall and Thancoupie]).

Comments: Doughboy was mother's father to Joyce Hall, Thancoupie and others. [Inclusion of this land in the Wik-Way area by others is not accepted by Joyce Hall—or is it that she rejects the appellation 'Wik-Way' on the basis that, while a custodian of this estate, she herself is not Wik-Way because her primary identification is with her father's area further to the north?].

\section{Code: L10}

\section{Standard name: Ngkoth}

Source spellings: Thomson: N'got'tungit; McConnel: Nggot; Capell: Nggwat (1955), Nggod (1963); Hale: Ngkoth; Hinton (1963): Ngotsh, (1964): Ngot; Bos: Nggoth; Sommer: Nggoth; Sutton: Ngkoth, Chaa'ngkooth ('language + ngkoth').

Source locations: McConnel: 'between the Embley River and the Hey inlet'; Capell: 'South side of Embley River near Weipa'; Hale: 'between the Embley and Hey Rivers south of their junction. The original site of Weipa Mission is said to have been in Ngkoth country.' Hinton (1964 map): east side of lower Hey River. Bos: Hey River, Hey and Embley rivers; Sommer: Akakan, Imbiorr, Kikelcha, Kuakanam, Mburrip, Ombon, Undrrang; Sutton: Estate 51: the south-eastern half, roughly, of the upper drainage system of the Hey River. 
People: Hinton: Monty Motton, Frank Motton, Ruth Motton, Samuel Harry. Bos: Samuel; mother of ?Cyril Hall; Sutton: Clan 50 (Motton).

Comments: Hale: The name is from ngko 'this'. 'Informants state that Ngkoth and the presumably extinct Trotj are closely related dialects.' Compare Roth's unidentified 'Gautundi' of the lower Hey.

\section{Code: L11}

\section{Standard name: Trotj}

Source spellings: Sharp: [may be same as his 'Kauwala']; McConnel: To.tj; Wikalata; Capell: Do:dj; Hale: Trotj; Tindale: Totj, To:tj; Bos: Trootj, Trrotj; Sommer: Trotj.

Source locations: [Sharp: (map) inland south-east of Albatross Bay]; McConnel: To.tj: 'on Myall Creek (upper Mission R.) and Cox Creek (upper Batavia R.)' (map has name between Myall and Cox Creeks); Tindale: Upper Mission River and Cox Creek (middle Batavia River); at York Downs; south to near Merluna; McConnel '28: Wikalata: 'There is another Wik tribe too which I did not record which is further north again, the Wikalata, which is at York Downs station \& links up probably with the Wik ampamas on the Watson River'; Bos: 'Merluna Way, Pitch Lagoon (< dog c pitchy)', '20m $\rightarrow$ York Down'; 'trotj baiwum (York Downs)'; Sommer: Waipa, Bingay, Jabiru Scrub, Yipatjiku (Billy Lagoon), Nonda Spring.

People: Bos: Alice and her sister Topsy (latter married Peter Costello's stepfather George).

Comments: Hale: very close linguistically to Ngkoth, and 'presumably extinct'. Jean George told Bos that Trootj spoke Baiwum (see L20). Bos pairs languages Trrotj and Yaath in the York Downs area.

\section{Code: L12}

\section{Standard name: Arrithinngithigh}

Source spellings: Thomson: Aredinngit; McConnel: Aritingiti; Capell: Aritingiti (MS), Aratingiti (1962), Aridingidigh (1963); Gajdusek: Aredinngit (Arichenite); Hinton (1963): Aretangnit, (1964): Aritenwum; 
Hale: Aritinngithigh, Aritinngayth; Tindale: Aretingit; Bos: Arraithingwum; Sommer: Araythingwum - Araythingum; Sutton: Arraythinngith, Arrithinngithigh, Arreythinwum depending on language used.

Source locations: Thomson: (map) upper Hey River, south-east area; McConnel: 'on Hey Inlet' (map has it covering all the drainage into Hey River inlet); Capell: 'South of the Hey River', (map) about the upper Hey River; Hale: 'around the head of the Hey River'; Tindale: 'Upper Hay (sic) River and across to Pera Head' (map has it midway between the two); Bos: immediately to the south of Nggoth (see L10); Sommer: Hey River salt creeks, saltpans, swamps and lagoons, including Anhanggun, Atakun, Poghadhim; Sutton: Estate 52, Onhánggun area, i.e. The south-western creeks and associated drainage area of the upper Hey River system.

People: Thomson: Andrew, Luke, Bosun, Kallappi, Old Charlie Fish, Daniel (schoolboy); McConnel: Ch. Fish, Andrew; Hinton: Daisy Brodie, Gibson Jankai, Mark Andrew; Sutton: Clan 51 (surnames: Mark, Kangaroo, Daisy Brodie).

Comments: Tindale appears to have conflated Arrithinngithigh with Aditinngithigh. Called Arrithinngithigh in Linngithigh, and Arritinngayth in Ndrwa'ngayth; named after the Arrithinngithigh verb arri- 'to go'; Linngithigh, by contrast, has li- (Hale). The version Arraythingwum appears to be in a neighbouring language having -wum as the comitative suffix (cf. Yinwum).

\section{Code: L13}

\section{Standard name: Adithinngithigh}

Source spellings: Sharp: Aditinngeti; Thomson: Additin'ngitti, Addedin'ngitti, Addenin'ngit (MS), Addedinngit (map); McConnel: Adetingiti; Capell: Adidingidigh; Tindale [see L12]; Sutton: Adithangath.

Source locations: Sharp: (map) inland from Pera Head; Thomson: (map) along coast from Pera Head to about Winda Winda Creek; McConnel: 'of Pera Head vicinity' (map has it at Pera Head and north-east along coast adjoining her Mamangiti); Capell: 'Mouth of Embley River'; Tindale: [see L12]; Sutton 83:36: at Pera Head, Estate 40. 
People: Thomson: Violet, Colin, Mabel, Harry (sent to Palm Islandfather of Mabel); Sutton: Animbi, Maggie Animbi, Harry Lifu (Luipo). Sutton: Formerly Clan 66 (that of Mabel [née Taisman] Pamulkan), now extinct.

\section{Code: L14}

\section{Standard name: Ndra'ngith}

Source spellings: Sharp: Anda'angeti; Thomson: N'dra'ngit (MS), N'drangit (map); McConnel: Ndra'angit (text), Ndraangit (map); Capell: Ndra?angid; Hale: Ntra’ngith; Tindale: Ndraangit; Sommer: Ndrra'ngith.

Source locations: Sharp: (map) coast south of Pera Head; Thomson: (map) coast south of Pera Head; McConnel: 'of False Pera Head vicinity' + map; Hale: 'around False Pera Head and the Norman River'; Tindale: 'Coast near False Pera Head' + map; Sommer: Akakan, Amban, Ikalath, Imbiorr, ?Ivikin, Kikelcha, Kuakanam, Mburrip, Nombon $\sim$ Nombuan, Pimpim, Pirri (Pera Head) (disputed with Linngithigh), Undrrang.

People: Thomson: Goodman, Albert, Kerring'gan; Blind Captain, Yg. Jack, Norman. Capell (1963): '3 possible [linguistic] informants are at Aurukun: Sam and Angus Kerindun and Jimmy Clark'.

Comments: Although separated from Awngthim language-speaking groups (see L1, L2, L8) by Linngithigh and Arrithinngithigh, it was more closely related to Awngthim than to the intervening forms of speech; the name comes from ntra 'this' (Hale).

\section{Code: L15}

\section{Standard name: Linngithigh}

Source spellings: Thomson: Lin'ngitti; McConnel: Leningiti (map and 1940 text), Leini-ngiti (1939 text); Capell: Leningiti (MS, 1962), Lenngidigh (1963); Gajdusek: Linngitti; Hinton: Linginiti; Hale: Linngithigh; Tindale: Leningiti; Bos: Liningati, Lininget; Martin: Liinangithiy [Wik-Mungkan version]; Sommer: Liningith.

Source locations: Thomson: [does not appear on map]; McConnel: 'extend southwards to the Archer River'; map has it extending from Aurukun two thirds of the way north to the head of Hey River inlet; 
McConnel: the inland side of the Ward River (+ map); Hale: 'south-west of the Embley River and west of the Hey in the area called Winduwinda' as located by his informants in 1960 but considers McConnel's location further south to be perhaps more accurate; Capell: (map) just south of Hey River, but 1963: 'Near Duifken [sic] Point and Weipa Mission Station' [appears to refer to Laynighithi = Alngith, see L5]; Tindale: 'West of lower Watson River and at Aurukun' + map. Hinton (1964 map): north of Aurukun. Martin: (map) west and south of Hey Point, False Pera Head area south-east of Norman river; Sommer: Aniyam, Mangrove Creek, Ivikin, Kokanin (Coxy Point and environs), possibly Lidhing, Maingum (contested with Latamngith), possibly Meunyam, Ndrrilkiyatj, Nggoray(thim), Pirri (Pera Head, disputed with Ndrra'ngith), Prendjim, Thitj.

People: Thomson: Violet's mother, Dick, Barry—son Joseph, Sam, Angus, Maggie, Jimmy Clarke, [then follows a list given as 'Same \{N'dwangit (gerri'gerri) (Some at Weipa and Mapoon)', being: Billy Blowhard, Blink Jack, Tankappi, Anang'gan\} the Lin'ngitti list continues:] Myrtle, Frederik (sic). McConnel: Anthony, Louie, Angus, Myrtle [on published genealogies]. Hinton: Lawrence Matthew, Maria Matthew, Minnie Matthew, Betty Robinson. Hale: Sam Kerindun. Martin: Myrtle Chevathun, Kerinduns; Norman Go'olfrey, his country marked on map as Liiningathiy but 'claimed by all Wik Way people as joint area' (but see Ndra’ngith); Sommer: Matthews.

Comments: McConnel erroneously identifies Roth's Laini-ngadi (and Sharp's Lenngeti?) as Linngithigh, but see L7 Alngith). Capell (1963) gives 'Ndorndorin' as the name of a language 'Not accurately located but in area covered by Aurukun Mission'; this is a male personal name. Capell said a speaker of it was Jimmy Clark who lived at Aurukun; Ndorndorin was Jimmy Clark's Big Name (Aurukun Mission records). Tindale (1974:190) erroneously gives 'Ndorndorin (a horde name)' under 'Winduwinda'.

\section{Code: L16}

\section{Standard name: Andjingith}

Source spellings: Thomson: Andjingit (map), Andjingitti (MS); McConnel: Andyingit; Gajdusek: Andjingit; Capell: Andjingid; Tindale: Anjingit; Sutton: Andjingith, Wik-Ayangench (Wik-Mungkan version); Martin: Wik Ayangenych, Anychangithiy; Aak: Wik-Ay.ngenych. 
Source locations: Thomson: (map) Wallaby Island (in Archer River) north along coast to just south of Norman River; McConnel: coastal side of the Ward River south to Wallaby Island (+ map); Gajdusek: 'On the coast north of the Archer River'; Tindale: 'Coast just north of Archer River' + map (map excludes Wallaby Island and Wuthan); Sutton: Estates $34,35,36,43$ and 57, probably 56, and formerly also estates 1, 2, 3 and 4, i.e.: from the south side of Norman River at Ichetang south via Waterfall and Ikeleth to the north side of the lower Archer at Wuthan and probably Yagalmungkan, south to the Yaaneng area on the other bank, up the Ward River to Paydan; formerly also upper Love River, now changed to Wik-Mungkan, formerly also lower Love River, now by succession Wik-Elken, formerly also Small Lake (Peret/Watha-nhiin Outstation area), now by succession Wik-Ngathan, and south again to Big Lake and the northern shores of the Kirke estuary (now only Wik-Ngatharr, by loss of Andjingith). Martin: (map) north side of mouth of Archer River, upper Ward River, east side of Ward River at e.g. Cowplace Survey Camp, Kampchin. Aak: Lower Archer, Bottom Love River (formerly), Top Love River (formerly), Small Lake (formerly), Big Lake (formerly).

People: Thomson: Mukkurrutt (female), Yukai, Robert; Sutton: William and his sons Jack and Norman Williams, from Wuthan area, also Myrtle (a refused promise of Colin Wolmby), and possibly Jacob Wolmby's mother's father Charlie William); Old Stephen Owokran and his brother Gilbert, whose daughter Barbara Owokran was Alison Woolla's mother, Old Murray and Cockatoo, and Cockatoo's half sister Thaankup, of lower Love River; Tharreway (male), Colin and Murray and their sister Kaalep ('Carlippe'), Rex Walmbeng's mother; Old Coconut of Small Lake and his brother Johnny and sister 'Wikatukkin' (Wik-thakenh, Chaalemnganh), and probably old Arraman of Big Lake. Martin: Wuthan area: Mokarathan et al., Geraldine Kawangka’s MM?, claimed by Fred Kerindun, disputed estate on north side Archer mouth; Alan Wolmby (his birthplace area of Ikelath), interests in Ikelath being pursued by his son Rex; east side of Ward River: Cyril Owokran, Alma Moon (Morn. Is.), Jimmy and Gibson Clark, Alison Woolla's MM. Aak: Clan 1 (Old Murray, Cockatoo), Clan 2/29 (Peinkinnas, Taismans, formerly), Clan 60 (Owokran A.), Clan 82 (Old Stephen Owokran).

Comments: Known as Wik-Ayangench in Wik-Mungkan, Wik-Ngathan and other Wik languages. 


\section{Code: L17}

\section{Standard name: Wik-Thint}

Source spellings: Thomson: Wik Tinda; McConnel: Wikatinda; Gajdusek: Wik-Tinda; Capell: Adinda; Tindale: Wikatinda.

Source locations: Thomson: (map) on coast south of Archer River mouth; McConnel: 'the coastal strip from the mouth of the Archer River at Ya.nung to the Tokali [Love] River, eight miles to the south' (1939+ map) but her 1957:xvii map has 'Wik-Kalkan' [i.e. Wik-Alken] extending to here from Cape Keerweer, and no trace of Wik-Thint or Wik-Paach; Tindale: 'on the coast from Archer River south for about 8 miles (13 km.)'; Sutton: [no record of Wik-Thint, but dialect from here named totemically as Wik-Thum ('Fire Language') and area associated with Andjingith and Wik-Paach languages].

People: [information not available]

Comments: Thomson did not include them in his Wik-Way list, and McConnel specifically numbered them among the Wik 'tribes', as did Gajdusek (the 'Wik-coastal tribes'). Tindale essentially reproduces McConnel's data. From the little information available, however, the language of the area, however named, appears to have been more like the other Wik-Way languages to the north.

\section{Code: L18}

\section{Standard name: Wik-Paach}

Source spellings: McConnel: Wikapatya (map), Wika-pa.tya, Wikapatya (text); Tindale: 'Wik'apatja; Sutton: Wik-Paach, and probably the language variety also known as Wik-Ngaangungker (by Cape Keerweer people); Aak: Wik-Paach.

Source locations: McConnel: 'the mangrove-clad islands and southern banks of the wide-mouthed Archer River' + map; Tindale: 'centred on the mangrove islands of Archer River delta' + map (map shows it including Wallaby Island, assigned by McConnel to L16 Andjingith); Sutton: formerly south of Archer River, including Bamboo Station and Yaaneng 
areas, lower Love River area (now Wik-Elken by succession), and upper Love River (now changed to Wik-Mungkan); Aak: Bottom Love River (formerly), Lower Archer, Yaaneng.

People: McConnel: Mukana (female); Sutton: Maraya (?Maria) who was Ian Peinkinna's mother's mother (?Bamboo area, as Piinth-Eempel was their nickname in Wik-Ngathan), Old Murray (Maarriy) and Cockatoo (see also Andjingith), Stephen Owokran of Yaaneng; formerly also Peinkinnas and Taismans (now Wik-Mungkan). Aak: (Clan 1) Old Murray, Cockatoo; (Clan 2) Peinkinnas (formerly); (Clan 82) Old Stephen Owokran.

Comments: McConnel: 'known as the "mangrove people"'.

McConnel specifically numbered them among the Wik 'tribes'. Tindale essentially reproduces McConnel's data. From the little information available, however, the language appears to have been more like the other Wik-Way languages to the north.

\section{Code: L19}

\section{Standard name: Kuuk-Yala (?)}

Source spellings: Mathews: Kookeealla; McConnel: Kokiala; Sharp: Kok Iala.

Source locations: Mathews: [CYP]; Sharp: (map) east of lower Archer; McConnel '28: Kokiala: 'on Kokialo Creek $\wedge$ near to mouth of the $\operatorname{Archer}^{\wedge} \&$ which apparently spread along the N. bank of the Archer to the middle of the Peninsula. The other, Koki awa, tribe is on Sefton Creek, the head of the Batavia \& runs down towards the Kokialas on the Archer ... There is another Wik tribe too which I did not record which is further north again, the Wikalatha [see Trotj above], which is at York Downs station \& links up probably with the Wik ampamas on the Watson River.'

People: Kokialah Creek is currently under the custodianship of Clan 33 and described as part of their estate, although their estate (31) centres on Mukiy and the Small Archer (Tompaten Creek) system to the south. This may be a case of succession by amalgamation, assuming Kokialah Creek was formerly the country of a clan now extinct. 
Comments: The Matthews, McConnel and Sharp records may represent Kuuku-Yala or possibly Kuuk-Iiyala ('language-go'?), which would be a possible Kaantju name for a Wik language but one not recorded as such. The Kokialah Creek name has been recorded as Kok-yal(a) by von Sturmer and Sutton, but this may have come into Wik via English, losing the long first vowel. So far, I am not aware of any record of the language so it is hard to know where it belongs in terms of linguistic subgroups, but I was told it was similar to Wik-Mungkan.

\section{Code: L20}

\section{Standard name: Mbiywom}

Source spellings: Thomson: M'berwum (map), Mberwum (MS); Sharp: Kok Mbewam; McConnel: Mbeiwum (map), (M)beiwum (text); McConnel: Wik-ampama, Wikampama; Capell: Mbeiwum, Ambama; Hale: Mbiywom; Hinton: Mbywum; Tindale: Mbewum, Mbe:wum (map), Wikampama; Bos: Baiwum (language of Trotj); Sutton: Mbiywum, Mbeywom, Wik-Ompom, also known as Orrkel; Martin: Wik Ompam; Aak: Wik-Ompoma.

Source locations: Thomson: (map) middle Embley River; Sharp: (map) upper Watson system; McConnel: Mbeiwum: 'on the Watson River' (map has it on the upper Watson); McConnel '28: Wikalatha: 'There is another Wik tribe too which I did not record which is further north again, the Wikalatha, which is at York Downs station \& links up probably with the Wik ampamas on the Watson River'; Wik-ampama: 'the middle Archer River and its tributary, Piccaninny Creek', 'on the upper Watson River and Piccaninny Creek' + map (map has it ranging between Kokialah Creek and Piccaninny Creek); Tindale: 'Middle Archer River; north to Watson River'; Sutton: Watson River area; Martin: upper Watson River, Moonlight Creek, Watson Crossing, Maanychawanh, Kilpatrick Station Landing, south to Merkunga Creek at e.g. Otwalanyin, Parrp-aw. Aak: Watson River. Gajdusek: M-Berwum (Bywoom); Hale: 'on the middle and upper Watson River and, more recently, on Myall Creek. York Downs and Merluna cattle stations are regarded by informants as being in Mbiywom country'; Tindale: 'Upper Watson River; at Merluna. Parry-Okeden has a name like Kokimoh (partly illegible on his map) in the area occupied by this tribe' [cf. Mathews 'Kokinno', Thomson (map) Koko I'o and its neighbour Yina]; Bos: 'trotj baiwum (York Downs)', Merluna way, Pitch 
Lagoon; Sutton: Estates 29, 30, 33, 65 i.e. lower Watson River, middle Watson River, Oyonton/Watson Crossing area, east to Green Swamp/ Layngay area on the upper Archer River.

People: Thomson: Annie, Hope, Dan (and 'plenty at Weipa'). Hinton: Willy George, Theresa Motton, Martha Dick; Bos: Alice and her sister Topsy (latter married Peter Costello's stepfather George)—and these Georges? Sutton: George family, Parkers and Days (all Clan 48), also late Koo'ekkas of Watson River (Clan 36), and Dan and Hope, Connie Clark (mother of Bessie Savo) and Polly Fruit (mother of Matthew and Lawrence Fruit) of extinct Clan 46, and Clan 75 (descendants of Charlie Kepple); Martin: Roy George, Willy George, Benny George et al; Eddie John's (Saul's) M country; Andrew Golpendun, Daisy Brodie et al. Aak: Clan 36 Koo'ekkas, Clan 48 Georges.

Comments: Thomson's location agrees with none of the others and is clearly too far north. The name Mbiywom probably comes from its word mbiy 'camp' (Hale). Bos records the unusual view that Mbiywom is the language of Trotj people. The evidence so far points to this being the same language as the one named Wik-Ompom in Wik languages. The latter is how its naming is understood by current members of relevant families.

McConnel regarded the 'Wikampama' as being one of the Wik 'tribes', partly on the grounds of the nature of their kinship classification system. They do not, however, claim a language of the Wik linguistic type (some still know parts of the language), as Mbiywom is quite different. The Mbiywom people, however, now mostly speak Wik-Mungkan as their main Aboriginal language.

Alice Mark said the language of Victoria, mother of Ronnie John, was Thaatj, and that Victoria was from a place called in her own language (Anathangayth) Eyvye [ejvjə], which is between Watson River and Green Swamp on the upper Archer. This would put this language at the location of Estate 65 and thus Thaatj may be another outsider-name for Mbiywom.

\section{Wik Subgroup languages}

Prior to the present research project, the state of academic knowledge of the names and locations of Wik-Way-type languages was in some disarray owing to the large number of language names recorded and the fact that some of them were so similar as to be easily confused with each other 
(e.g. Arrithinngithigh, Adithinngithigh, and Ndrra'ngith, Ndrrwa'ngith). For this reason, those languages have here been dealt with above in considerable detail.

For the Wik Subgroup languages the situation is less confusing, since the $\mathrm{PhD}$ theses of Sutton and von Sturmer already provide surveys of literature sources on these language names (Sutton 1978:36-41, Maps 7 and 8; von Sturmer 1978:572-79, Map 3). The nature of interrelationships among Wik Subgroup languages, and between them and others, is explored in some technical detail in Ken Hale's chapters here on the question of the time-depth and geographical stability of the Wik Subgroup languages. A graphic illustration of a preliminary statement of genetic relationships among Wik Subgroup languages is provided in Sutton (1991:60).

In Tables A1.1 and A1.2 below, I provide a numerically ordered list of such estates and their relevant languages, with an alphabetised reversal. Here I list them very approximately from north to south, starting at the lower Archer River and proceeding south via the drainage systems of Love River, the middle and upper Archer River, the Kirke River, Knox River, Kendall River, Hersey Creek, Holroyd River, and Edward River.

Table 5.9: Wik Subgroup varieties schematically listed from north to south

\begin{tabular}{|l|l|l|}
\hline COASTAL & PERICOASTAL & INLAND \\
\hline & Wik-Mungkan & \\
\hline Wik-Elken & Wik-Alken & Wik-Mungkan \\
\hline Wik-Ngatharr & Wik-Ep (aka Wik-lit) & Wik-Mungkan \\
\hline Wik-Ngatharr & Wik-Me'enh & Wik-Mungkan \\
\hline Wik-Mungkan & Wik-Ngathan, Wik-Ngatharr & Wik-Mungkan \\
\hline $\begin{array}{l}\text { Wik-Ngathan (for a time: } \\
\text { Wik-lincheyn) }\end{array}$ & Wik-Ngatharr & Wik-Mungkan \\
\hline Wik-Ngatharr & Wik-Keyenganh & Wik-Mungkan \\
\hline Wik-Mungkan & Wik-Keyenganh & Wik-Mungkan \\
\hline Wik-Ngathan & Wik-Ngathan & Wik-liyeyn \\
\hline Kug-Ugbanh & & \\
\hline Kugu Muminh & Wik-liyanh & Mungkanhu \\
\hline Kug-Uwanh & & \\
\hline Kugu Muminh & & \\
\hline Kug-Uwanh & Kug-liyanh & Wik-liyanyi \\
\hline Kugu Mangk & & \\
\hline Kug-Ugbanh & & \\
\hline
\end{tabular}




\begin{tabular}{|l|l|l|}
\hline COASTAL & PERICOASTAL & INLAND \\
\hline Kugu Mu'inh & & \\
\hline Kugu Muminh & & \\
\hline Kugu Mu'inh & & \\
\hline Kugu Mangk & & Pakanh \\
\hline Kugu Mu'inh & & \\
\hline Kugu Mangk & & \\
\hline Kugu Muminh & lyanh/Pakanh & \\
\hline Kugu Mu'inh & & \\
\hline Kugu Mangk & Kugu-Yi'anh & Ayapathu \\
\hline
\end{tabular}

A few of these names are more or less equivalents and represent usages in different local speech varieties. These are:

Wik-Alken $=$ Wik-Elken $=$ Wik-Ngatharr

Wik-Iiyeyn $=$ Wik-Iiyanh $=$ Wik-liyanyi $=$ Mungkanhu

Wik-Ngathan $=$ Wik-Iinycheyn

Thus far I have generally referred to any distinctively named speech variety in this context as a 'language' or a 'language variety'. Various subsets of the varieties listed immediately above, however, are mutually intelligible, sharing most of their grammars and lexicons. These sets of close varieties thus constitute what linguists-not the Wik people themselves in general-would call dialects of single languages. As a preliminary statement, those sets are as follows: ${ }^{10}$

1. (a) Wik-Alken $=$ Wik-Elken $=$ Wik-Ngatharr; (b) Wik-Ngathan $=$ Wik-Iinycheyn

2. (a) Wik-Mungkan; (b) Wik-Iiyeyn $=$ Wik-Iiyanh $=$ Wik-Iiyanyi $=$ Mungkanhu

3. (a) Pakanh; (b) Ayapathu

4. (a) Wik-Ep = Wik-Iit; (b) Wik-Me'enh; (c) Wik-Keyenganh

5. (a) Kug-Ugbanh; (b) Kugu Muminh; (c) Kug-Uwanh; (d) Kugu Mangk; (e) Kugu Mu'inh; (f) Kugu Yi'anh

10 It is possible that southern inland varieties of language 2 form a dialect chain continuous with language 3; further work is required on this. 


\section{Estates and their linguistic varieties}

Table 5.10: Estates and their language affiliations

\begin{tabular}{|c|c|c|c|}
\hline ESTATE & LANGUAGE & ESTATE & LANGUAGE \\
\hline 1 & An & 21 & $\mathrm{Nn}$ \\
\hline 1 & $\mathrm{~Pa}$ & 22 & $\mathrm{Nn}$ \\
\hline 1 & $\mathrm{El}$ & $23 ?$ & $\mathrm{Me}$ \\
\hline 2 & An & $23 ?$ & In \\
\hline 2 & $\mathrm{~Pa}$ & 24 & $\mathrm{Nn}$ \\
\hline 2 & Mn & 25 & Uw \\
\hline 3 & An & 26 & $?$ \\
\hline 3 & $\mathrm{Nr}$ & 27 & Ep \\
\hline 3 & $\mathrm{Nn}$ & 27 & $\mathrm{Mn}$ \\
\hline 4 & An & 28 & $\mathrm{Mn}$ \\
\hline 4 & $\mathrm{Nr}$ & 29 & $\mathrm{Mb}$ \\
\hline 5 & Ep & 29 & $\mathrm{Mn}$ \\
\hline 5 & $\mathrm{Al}$ & 30 & $\mathrm{Mb}$ \\
\hline 6 & $\mathrm{Nn}$ & 31 & $\mathrm{Mn}$ \\
\hline 7 & $\mathrm{Nr}$ & 32 & $\mathrm{Mb} ?$ \\
\hline 8 & $\mathrm{El}$ & 33 & $\mathrm{Mb}$ \\
\hline 9 & El & 34 & An \\
\hline 10 & It & 35 & An \\
\hline 10 & Ep & 36 & An \\
\hline 11 & $\mathrm{Nr}$ & $37 ?$ & $\mathrm{Mn} ?$ \\
\hline 12 & Mn & 38 & $\mathrm{Nd}$ \\
\hline 13 & Ep & 39 & Mt \\
\hline 13 & $\mathrm{Me}$ & 40 & $\mathrm{Ad}$ \\
\hline 14 & Me & 41 & $\mathrm{Nd}$ \\
\hline 14 & Mn & 42 & $\mathrm{Mn}$ \\
\hline 15 & In & 43 & $\mathrm{~Pa}$ \\
\hline 15 & $\mathrm{Nn}$ & 43 & An \\
\hline 16 & $\mathrm{Me}$ & 44 & $\mathrm{~Pa}$ \\
\hline 17 & Mn & 45 & $\mathrm{Li}$ \\
\hline 18 & $\mathrm{El}$ & 46 & At \\
\hline 19 & $\mathrm{Nn}$ & 47 & $\mathrm{Li}$ \\
\hline 20 & $\mathrm{Mn}$ & 48 & lyn \\
\hline 21 & El & 49 & lyn \\
\hline
\end{tabular}


5. LANGUAGES OF THE WIK NATIVE TITLE CLAIM AREA

\begin{tabular}{|c|c|}
\hline ESTATE & LANGUAGE \\
\hline 51 & Nk \\
\hline 52 & $\mathrm{Ar}$ \\
\hline 53 & La \\
\hline 55 & $\mathrm{Mb} ?$ \\
\hline 56 & An? \\
\hline 57 & An? \\
\hline 58 & $\mathrm{Mn}$ \\
\hline 59 & ly \\
\hline 60 & ly? \\
\hline 62 & ly \\
\hline 63 & ly \\
\hline 64 & Ay \\
\hline 65 & $\mathrm{Mb}$ \\
\hline 66 & Mn \\
\hline 67 & Iyi \\
\hline 68 & Rn \\
\hline 69 & $\mathrm{Na}$ \\
\hline 105 & Me \\
\hline 105 & $\mathrm{Nn}$ \\
\hline 106 & Ug \\
\hline 107 & $\mathrm{Mm}$ \\
\hline 108 & $\mathrm{Mm}$ \\
\hline 109 & $\mathrm{Mm}$ \\
\hline 110 & Uw \\
\hline 111 & ly \\
\hline 112 & ly \\
\hline 113 & ly \\
\hline 114 & ly \\
\hline 115 & Mh? \\
\hline 115 & ly \\
\hline 116 & ly \\
\hline 117 & ly \\
\hline 118 & ly \\
\hline 119 & ly \\
\hline 120 & Ay \\
\hline 121 & $\mathrm{Mm}$ \\
\hline
\end{tabular}

\begin{tabular}{|l|l|}
\hline ESTATE & LANGUAGE \\
\hline 122 & ly \\
\hline 123 & Uw \\
\hline 124 & $\mathrm{Ug}$ \\
\hline 125 & $\mathrm{Ug}$ \\
\hline 126 & $\mathrm{Mu}$ \\
\hline 127 & $\mathrm{Mm}$ \\
\hline 128 & $?$ \\
\hline 129 & $\mathrm{Mm}$ \\
\hline 130 & $\mathrm{ly}$ \\
\hline 131 & $\mathrm{Mu}$ \\
\hline 132 & $\mathrm{Yi}$ \\
\hline 133 & $\mathrm{Mu}$ \\
\hline 134 & $\mathrm{Mu}$ \\
\hline 135 & $\mathrm{Mu}$ \\
\hline 136 & $\mathrm{Ma}$ \\
\hline 137 & $\mathrm{Mm}$ \\
\hline 138 & $\mathrm{ly}$ \\
\hline 139 & $\mathrm{Ma}$ \\
\hline 140 & $\mathrm{Pk}$ \\
\hline 141 & $\mathrm{Pk}$ \\
\hline 142 & $?$ \\
\hline 143 & $\mathrm{Mu}$ \\
\hline 144 & $?$ \\
\hline 145 & $?$ \\
\hline 146 & $\mathrm{At}$ \\
\hline 147 & $\mathrm{Li}$ \\
\hline 148 & \\
\hline 149 & \\
\hline
\end{tabular}


This text is taken from Linguistic Organisation and Native Title: The Wik Case, Australia, by Peter Sutton and Ken Hale, published 2021 by ANU Press, The Australian National University, Canberra, Australia.

doi.org/10.22459/LONT.2021.05 